\title{
Choice and Application of Marketing Strategies of Selected Book Publishers in Nigeria
} By

\section{Johnson E. Akpane}

\begin{abstract}
The study was designed to identity the type of marketing strategies employed by book publishers in Nigeria, the criteria for the choice and application of marketing strategies, being used to reach each segment of the market. The survey research method was adopted for the study. Forty market managers and 60 sales representatives drawn from selected publishing houses in Nigeria were sampled. The instruments used for gathering data were questionnaire, interviews and documentary sources. Data gathered were analysed descriptively using tables and percentages. The study results indicated that book publishers in Nigeria employ various marketing strategies which contribute to the achievement of marketing objectives. However, in order to boost book trade, the opening of book depots in the rural areas, publishers to pool their resources together to stimulate mass production, the granting of credit facilities and the reduction of import duties on printing materials by government, were recommended in the study.
\end{abstract}

\section{Introduction}

Book trade or the marketing of books requires the application of appropriate marketing techniques to sale products to the consumers. Book publishers operate in an industry where the choices and decisions on the marketing strategies are crucial to the achievement of sales targets. Marketing calls for more than just developing a good product, pricing and making it available to target customers Kotler (2004) are very important. Other important marketing decisions involves the choice and application of competitive strategies to outwit other competitors in the market. The task of organizing a commercial network to dispose of books, involves decisions and choices in terms of tools and methods to be employed to promote and distribute same to end users. To do this effectively, requires a good knowledge of the market, its size, preferences, buying behaviour and the nature of competitors operating in the market. According to Smith (1990) the trading aspect of the book business is the life blood of the entire book industry. Hence the marketing and distribution process is critical to the availability of books.

\section{Statement of the Problem}

Nigeria is witnessing a tremendous expansion and increase in the number of educational institutions at all levels. At a time when the educational industry which depends on published materials is expanding rapidly. Ocheibi (2002) observed that the book publishing business had continued to experience poor sales. He posit that some of the challenges faced by the book trader recently includes:

1. Marketing forces which include the advent of electronic publishing and the availability of such publications in various non-print formats. This has made it possible for consumers to choose between buying the hard copy or the soft copy.

2. Internet marketing or sales of books on the net is another technological advancement that has a huge impact on the book publishing industry in general and book marketing in particular. Amazon.com has since 1995 been in the forefront of online book business.

3. The activities of pirates have continued to pose serious challenge to book industries. Publishers are being challenged to higher level of ingenuity to package and deliver books to customers within an established distribution network and to employ new channels of book distribution

4. Globalization has narrowed geographical distance, by encouraging direct purchase without.

In view of the above, it has therefore become imperative, that hard choices and decisions on marketing strategies has to be taken by book publishers This study is designed to investigate the choice and application of marketing strategies by selected book publishers in Nigeria.

\section{Objective of the study}

Thus the objective of the study includes:

1. To identify the types of marketing strategies book publishers employ in carrying out their business.

2. To identify the criteria for the choice of marketing strategies by book publishers in Nigeria.

3. To identify the types of promotional methods, and tools used by book publishers.

4. To investigate the role of distribution in the marketing of books. 
5. To find out in what ways the adopted marketing strategies contributes to the achievement of the publisher's objectives.

\section{Methodology}

The study employs the survey research method. Two sets of questionnaire were designed and administered on marketing managers and sales representative in selected book publishing houses in Nigeria. The random sampling technique was employed. Documentary survey and oral interviews were used also to collect data. Twenty six (26) set of questionnaire were returned by marketing managers and forty-three (43) of questionnaires were returned by sales representatives. The response rate of $65 \%$ and $71.60 / 0$ were obtained respectively.

\section{Discussion}

Findings show that book publishers in Nigeria employ various marketing strategies to promote and distribute their products to various segments of the market. The opinions of marketing managers on the type of marketing strategy they employ in the conduct of their business is presented in Table 1 bellow.

A very high percentage of the respondents 23 $(88.4 \%)$ agreed that the market leader strategy is adopted by their companies. Also, 18 (69.6\%) of the respondents agreed that their publishing house employ the challenger strategy.

This goes to conform the prominent attention that marketing managers give to the choice and application of competitive marketing strategies. A variety of strategic options are available to a firm. Scheme (1987) identified market leader strategy, challenger strategy, follower strategy and market nicher strategy as the specific strategies employed by films to conduct their marketing activities.

Various criteria are considered before a company selects any marketing strategy. Table 2 below presents the responses of the marketing managers on the criteria for the choice of a particular marketing strategy.

Table I: Opinions of respondents on type of marketing strategy employed

\begin{tabular}{|l|l|l|l|l|c|}
\hline Strategies & $\mathrm{SA}(\%)$ & $\mathrm{A}(\%)$ & $\mathrm{UD}(\%)$ & $\mathrm{D}(\%)$ & $\mathrm{SD}(\%)$ \\
\hline Market leader strategy & $19(73.0)$ & $4(15.3)$ & - & - & $3(11.5)$ \\
\hline Challenger strategy & $9(34.8)$ & $9(34.8)$ & $1(3.8)$ & $2(7.7)$ & $5(\quad)$ \\
\hline Market. follower strategy & $6(28.0)$ & $1(3.8)$ & - & $15(57.6)$ & $4(15.3)$ \\
\hline Market Niche strategy & $7(26.9)$ & $6(23.0)$ & $2(7.6)$ & - & $11(42.3)$ \\
\hline
\end{tabular}

Table 2: Publishers' criteria for choice of marketing strategies

\begin{tabular}{|l|c|c|c|c|c|}
\hline Criteria & $\begin{array}{c}\text { Very } \\
\text { High (\%) }\end{array}$ & $\begin{array}{c}\text { High } \\
(\%)\end{array}$ & $\begin{array}{c}\text { Undecided } \\
(\%)\end{array}$ & $\begin{array}{c}\text { Low } \\
(\%)\end{array}$ & $\begin{array}{c}\text { Very } \\
\text { Low }(\%)\end{array}$ \\
\hline Environmental factors & $13(50.0)$ & $6(23.1)$ & $3(1 \mathrm{~L} 5)$ & $1(3.8)$ & $3(11.5)$ \\
\hline Marketing objectives & $12(46.2)$ & $10(38.5)$ & - & $4(15.4)$ & - \\
\hline Competitors strategies & $8(30.8)$ & $8(30.8)$ & $2(7.6)$ & $3(11.5)$ & $5(19.2)$ \\
\hline Increasing market shares & $9(34.6)$ & $6(23.1)$ & - & - & $11(42.3)$ \\
\hline Penetration into new market & $11(42.3)$ & $8(30.8)$ & - & $7(26.9)$ & - \\
\hline
\end{tabular}


Majority $19(73.1 \%)$ of the respondents were of the opinion that environmental factors ranked very high among the .criteria for the choice of marketing strategies in their book publishing company. While 24(84.7\%) rated marketing objectives as a high criteria for the choice of marketing strategy, $16(61.6 \%)$ of them indicated competitors strategies as one of the determinant of their choice of marketing strategy.

The choice a company makes and the criteria for this choice are a critical factor for success in business. Therefore, the implication is that where a firm's marketing and sales objectives guide its operation in the market, it becomes easier to monitor performance and face competitors according to the dictates of the business environment.

The effectiveness of the promotional method employed by a firm facilitates the acceptability of its product in the market. The effectiveness of promotional methods used by book publishing companies in Nigeria is therefore presented in Table 3 bellow.

Sales representatives call (a form of direct sales to customers) accounts for 26(100.0\%) of the most useful method of promoting books to customers in Nigeria. Also rated as highly useful $22(84.6 \%)$ are exhibition, and book fair. This is indicative of the high level of direct involvement of publishers in the promotion and direct sales of books to end users in Nigeria.

Table 3: Promotional methods used by publishing companies

\begin{tabular}{|c|c|c|c|c|c|}
\hline Promotional methods & $\begin{array}{c}\text { Most } \\
\text { useful \% }\end{array}$ & Useful \% & $\begin{array}{c}\text { Undecided } \\
\%\end{array}$ & $\begin{array}{c}\text { Not useful } \\
\% \\
\end{array}$ & $\begin{array}{c}\text { Not useful } \\
\text { at all } \% \\
\end{array}$ \\
\hline Media reviews & $16(61.5)$ & $7(26.9)$ & $2(7.7)$ & $1(3.8)$ & - \\
\hline $\begin{array}{l}\text { Exhibition and Books } \\
\text { Fair }\end{array}$ & $12(46.2)$ & $10(34.5)$ & $3(1 \mathrm{i} .5)$ & $1(3.8)$ & - \\
\hline New arrival list & $16(61.5)$ & $6(23.1)$ & - & $1(3.8)$ & $3(11.5)$ \\
\hline Trade announcement & $8(30.7)$ & $4(15.3)$ & $10(38.5)$ & $4(15.3)$ & - \\
\hline Sales representative & $23(88.5)$ & $3(11.5)$ & - & & - \\
\hline Direct mail advertising & $13(50.0)$ & $6(23.1)$ & $3(11.5)$ & $4(15.3)$ & - \\
\hline Complimentary copies & $16(61.5)$ & $2(7.7)$ & $3(11.5)$ & $2(7.7)$ & $3(11.5)$ \\
\hline Window/Shop display & $18(42.3)$ & $4(15.3)$ & $8(30.7)$ & - & - \\
\hline $\begin{array}{l}\text { Radio and Television } \\
\text { advertising }\end{array}$ & $11(42.3)$ & $10(38.5)$ & $4(15.3)$ & $1(3.8)$ & - \\
\hline Poster and catalogue & $20(76.9)$ & $16(61.5)$ & - & - & - \\
\hline
\end{tabular}


Table 4: Distribution channels

\begin{tabular}{|c|c|c|c|c|c|}
\hline \multirow[t]{2}{*}{ Distribution channels } & \multirow{2}{*}{$\begin{array}{c}\text { Most } \\
\text { useful \% }\end{array}$} & \multirow[t]{2}{*}{ Useful \% } & \multirow{2}{*}{$\begin{array}{c}\text { Undecided } \\
\%\end{array}$} & Not. useful & \multirow{2}{*}{$\begin{array}{l}\text { Not useful } \\
\text { at all } \%\end{array}$} \\
\hline & & & & $\%$ & \\
\hline wholesales & $9(20.9)$ & $16(37.2)$ & - & $16(37.2)$ & $2(4.6)$ \\
\hline Retailer & $9(20.9)$ & $21(48.8)$ & - & $13(30.2)$ & - \\
\hline Bookshops' & $24(55.8)$ & 18(41.9) & - & $1(2.3)$ & - \\
\hline Libraries & $12(27.9)$ & $20(46.5)$ & $4(9.3)$ & $7(16.3)$ & - \\
\hline Agents & $15(34.9)$ & $13(30.2)$ & $3(6.9)$ & $7(16.3)$ & $S(11.6)$ \\
\hline Schools & $26(60.5)$ & $13(30.2)$ & - & $4(9.3)$ & - \\
\hline Subscription & $9(20.9)$ & 18(41.9) & - & $10(23.2)$ & $6(13.9)$ \\
\hline $\begin{array}{l}\text { Mass distribution } \\
\text { companies }\end{array}$ & $4(9.3)$ & $10(23.2)$ & $5(11.6)$ & $24(55.8)$ & - \\
\hline Mobil booksellers & $7(16.2)$ & 18(41.9) & - & $18(41.9)$ & - \\
\hline $\begin{array}{lll}\text { Direct } & \text { sales } & \text { to } \\
\text { individuals } & & \end{array}$ & $16(37.2)$ & $16(37.2)$ & - & $11(25.6)$ & - \\
\hline
\end{tabular}

The choice and the effectiveness of channel of distribution for the physical distribution of books plays very crucial role in its performance in the market. The opinions of sales personnel on the usefulness of the distribution channels are presented in Table 4 above. From the expressed frequencies and percentages of the respondents in the table above, $42(97.7 \%)$ of the respondents ranked bookshops as useful channel of distribution. Also, it is evident that $39(90.7 \%)$ of the sales representatives rated schools as the next most useful channel for the distribution of books in Nigeria. Direct sales to individuals 32(74.4\%) was ranked. highly by this group as indicated in their percentage score for the item. It can be observed that most of the respondents focus their attention on bookshops, schools and directs sales to individual' as the main channels of book distribution in Nigeria.

Concerning the ways in which marketing strategies contribute to the achievement of publisher company's objectives, the following responses in table 5 bellow were obtained. To ascertain the various ways in which marketing strategies contribute to the achievement of company objectives, findings revealed that $23(85.4 \%)$ of the respondents agreed that the application of marketing strategies gives direction to their marketing efforts. Furthermore, $22(84.6 \%)$ of the publishers agreed that the adoption of marketing strategies help them to stay ahead of their competitors. Interestingly, a mere $1(3.8 \%)$ of the respondents disagreed with the statement that marketing strategies help in the coordination of marketing activities.

It is obvious that findings here reinforced the paramount place of the choice and application of appropriate marketing strategies by book publishers as a competitive weapon in the marketing of books. 
Table 5: Ways in which marketing strategies contribute to the achievement of company objectives

\begin{tabular}{|c|c|c|c|c|c|}
\hline $\begin{array}{l}\text { Contribution of marketing } \\
\text { strategies }\end{array}$ & $\mathrm{SA}(\%)$ & $\mathrm{A}(\%)$ & $\mathrm{UD}(\%)$ & $\mathrm{D}(\%)$ & $\mathrm{SD}(\%)$ \\
\hline $\begin{array}{l}\text { Gives .- direction to } \\
\text { marketing efforts }\end{array}$ & $16(61.5)$ & $7(26.9)$ & $2(7.7)$ & $1(3.8)$ & - \\
\hline $\begin{array}{l}\text { Facilitates choices } \\
\text { tactics }\end{array}$ & $12(46.2)$ & $10(38.5)$ & $3(11.5)$ & $1(3.8)$ & - \\
\hline $\begin{array}{l}\text { Keeps us ahead of } \\
\text { competitors }\end{array}$ & $16(61.5)$ & $6(23.1)$ & , & $1(3.8)$ & $3(11.5)$ \\
\hline $\begin{array}{ll}\text { Ensures } & \text { effective } \\
\text { distribution of books } & \\
\end{array}$ & $12(46.2)$ & $10(38.5)$ & - & $2(7.7)$ & - \\
\hline $\begin{array}{l}\text { Ensures } \\
\text { promotion of books }\end{array}$ & $13(50.0)$ & $8(30.8)$ & - & $2(7.7)$ & $3(11.5)$ \\
\hline $\begin{array}{l}\text { Helps in the choice of } \\
\text { marketing mix }\end{array}$ & $10(38.5)$ & $11(42.3)$ & - & $1(3.8)$ & $4(15.4)$ \\
\hline $\begin{array}{lr}\text { Facilitates. planning } & \text { and } \\
\text { implementation } & \text { of } \\
\text { marketing activities } & \\
\end{array}$ & $14(53.3)$ & $10(38.5)$ & - & $2(7.7)$ & - \\
\hline $\begin{array}{l}\text { It helps in the coordination } \\
\text { of marketing activities }\end{array}$ & $10(38.5)$ & $11(42.3)$ & - & $1(3.8)$ & $4(15.4)$ \\
\hline 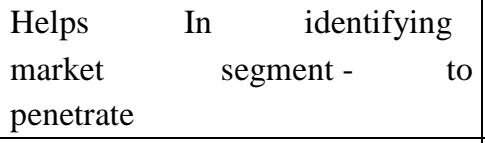 & $9(34.6)$ & $11(42.3)$ & $2(7.7)$ & $1(3.8)$ & $3(11.5)$ \\
\hline It facilitates market positioning & $9(34.6)$ & $11(43.3)$ & - & $3(3.8)$ & $3(11.5)$ \\
\hline
\end{tabular}

\section{Conclusion and Recommendations}

The study clearly revealed that that most book publishers in Nigeria employ various marketing strategies and to a large extend the strategic choice made by the book publishing companies influence the attainment of set objectives. From the foregoing, the following recommendations aimed at improving book marketing and availability in Nigeria is put forward:

1. In order to improve availability and access to published books, publishers in Nigeria should integrate Information and Communication Technology into their business functions. They should explore the potential of electronic publishing and the marketing of books via the internet.

2. The distribution of books to the rural areas can be improved by providing depots in the rural areas where schools and libraries are not being served adequately.

3. Publishers and printers in Nigeria should pool resources together to stimulate the mass production of books for use at all levels of education and for personal development. Where necessary, the smaller outfits should merge with the bigger players to consolidate the industry.

4. The enforcement of the copy-right laws should be pursued with more vigour and the war on book piracy should be fought in a more coordinated manner.

5. Book publishers should be encouraged by the Federal Government through the granting of credit facilities and low duties for importing printing materials. 


\section{References}

Toyyo, N. O. (2006). Book Distribution and Marketing Techniques in the Competitive world of Books. A paper presented at ETF Workshop on Book Development for Teachers in North-East Zone, Bauchi.

Adams, Nkechi, M. (2002). The Book Marketing Aspects of Nigerian Publishing. The publisher. Vol. 9, No. 1, pp. 46.

Adelakan, A. (2001). Digital (Virtual) Library, Electronic Education and Implication for the Publishing Industry". The publisher, Vol. 8, No. 2."

Momoh, K. Adu (2006). Book Business enterprise in selected University Bookshops in Nigeria. Unpublished Ph. D. Thesis. Department of Library and Information Science, A. B. U., Zaria.
Alabi, Dayo (1999). Strategies for promoting trade in Books, The Publisher, Vol. 6, No. 1.

Osadalor, O. J. (1985). Marketing decisions in. Publishing. Management in Nigeria, V 01. 21, No. 3.

Ocheibi, Jonathan A. (2002). "Printing and Publishing in Nigeria: Issues for the $21^{\text {st }}$ Century". Borno Library, Archival and Information Science, Vol. 1, No, 1.76-84.

Smith, D. (1990). A guide to book publishing Rev. ed. Lagos: University of " Lagos Press, 23 - 40.

Kotler Philip and Armstrong, G. (2004). Principles of marketing, $10^{\text {th }}$ ed. India: Pearson Education, Inc., 39 - 68. 